\title{
Subvolcanic Rock Petroleum System Potential in the South Malang Region, East Java, Indonesia
}

\author{
Carolus Prasetyadi, Achmad Subandrio, Muhammad Gazali Rachman, \\ Antu Ridha Falkhan Barizi, Guntor Suryo Putro \\ Departement of Geological Engineering, UPN “Veteran” Yogyakarta, Yogyakarta, Indonesia \\ Email: cprasetyadi@upnyk.ac.id
}

How to cite this paper: Prasetyadi, C., Subandrio, A., Rachman, M.G., Barizi, A.R.F. and Putro, G.S. (2021) Subvolcanic Rock Petroleum System Potential in the South Malang Region, East Java, Indonesia. Open Journal of Yangtze Gas and Oil, 6, 146-160.

https://doi.org/10.4236/ojogas.2021.64013

Received: August 10, 2021

Accepted: October 16, 2021

Published: October 19, 2021

Copyright $\odot 2021$ by author(s) and Scientific Research Publishing Inc. This work is licensed under the Creative Commons Attribution International License (CC BY 4.0).

http://creativecommons.org/licenses/by/4.0/ (c) (1) Open Access

\begin{abstract}
The South Malang Region is located in the south-eastern part of the Southern Mountain Volcanic Arc; it presents different opportunities for hydrocarbon exploration. The stratigraphy of the study area from old to young consists of Oligocene Volcanic rocks (Mandalika, Watupatok, and Arjosari Formation), Early Miocene Carbonates (Campurdarat and Jaten Formation), Middle Miocene Volcanic (Wuni Formation), Late Miocene-Pliocene Carbonates (Nampol, Oyo, and Wonosari Formation), and Holocene alluvial deposits (Kalipucang Formation). The dominance of volcanic rocks makes this area considered an area without hydrocarbon play prospects. Petroleum system potential is revealed by evaluating and analyzing potential source rock and reservoir rock outcrop samples. The study shows that the Nampol Formation can be considered as a gas-prone source rock, with type III kerogen, total organic content ranging from $3.48-26.18 \mathrm{wt} \%$, and possess the potential to produce good to very good hydrocarbons and a hydrogen index ranging from 43 to $86 \mathrm{mgHC} / \mathrm{g}$ TOC. Furthermore, rock core analysis and petrographic studies were carried out on the Nampol sandstone where the rock samples showed good reservoir properties. However, the Nampol and Wonosari limestone that was considered as the secondary target for reservoir possesses a low quality of reservoir properties. This study shows that there is a potential for petroleum system existence in the Southern Mountain subvolcanic arc, which is indicated by the presence of source rock and potential reservoir rock as one of the various elements and processes present in a petroleum system.
\end{abstract}

\section{Keywords}

Petroleum System, Reservoir, Source Rock, South Malang, Sub-Volcanic 


\section{Introduction}

The research area is located in the eastern part of Southern Mountain, more precisely in Malang Regency, East Java Province (Figure 1). The focus of this research is on the Nampol Formation and the Wonosari Formation which are expected to have the potential to become source rocks due to their organic material content, and to become reservoir rocks due to the presence of layers of sandstone and limestone which may have appropriate porosity and permeability properties. Shale, siltstone, calcareous claystone, and coal inserts [1] in this formation are thought to contain organic material that supports the presence of potential source rocks.
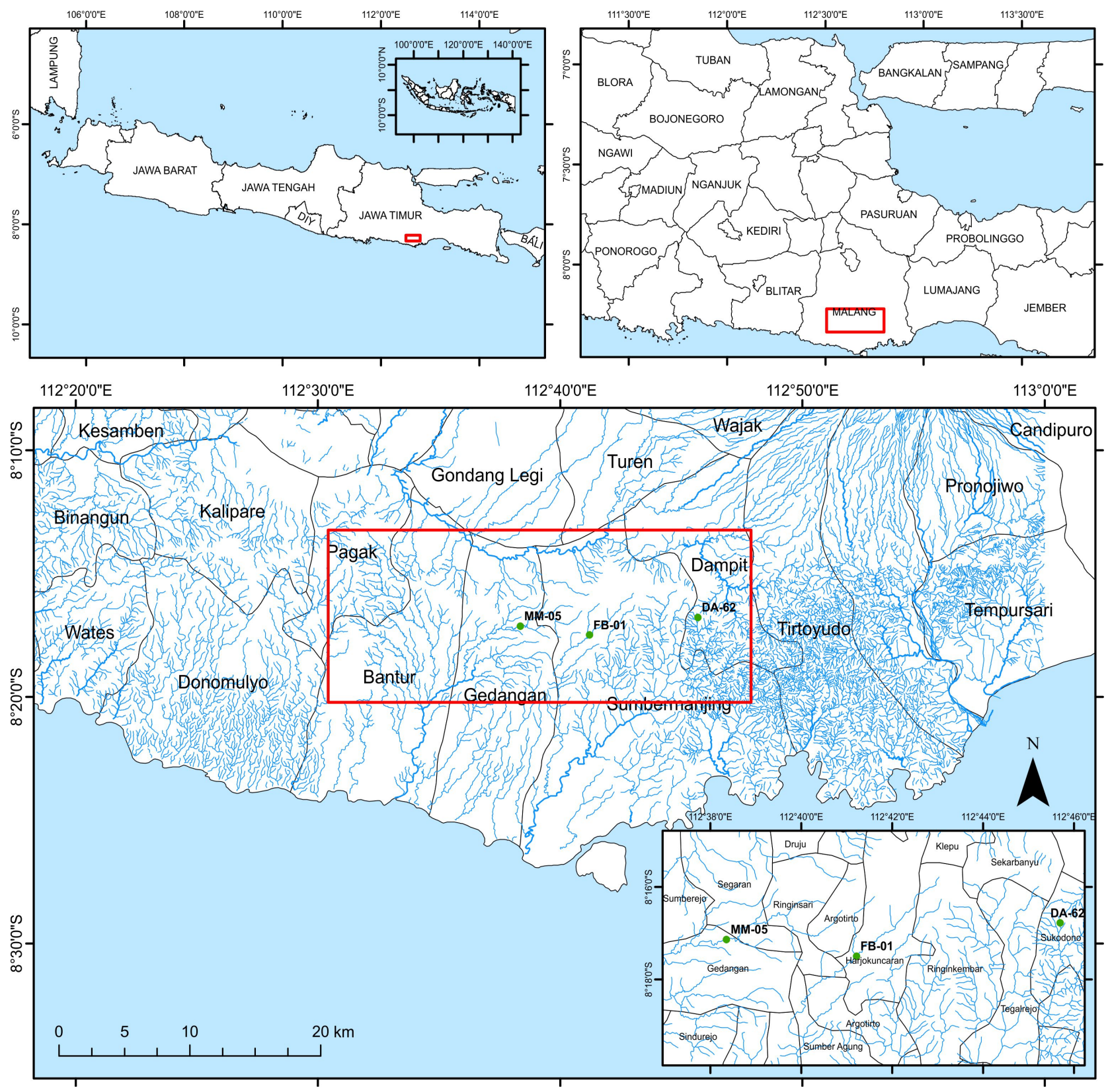

Figure 1. Research location (Map source from Geospatial Information Agency Indonesia). 
The objectives of this research are: 1) to investigate the possibility of potential source rock, 2) to identify the potential of sub-volcanic rock as a petroleum reservoir, 3) to obtain the petroleum system potential of the Southern Mountains East Java sub-volcanic arc.

\section{Methodology}

Detailed geological mapping was carried out in several selected tracks. Source rock samples taken from outcrops on the surface were analyzed to evaluate organic material content, type of kerogen thermal maturity, and its potential to produce hydrocarbons through TOC analysis and Rock-Eval pyrolysis. In addition, reservoir rock samples were also taken to analyze the quality of their properties through petrographic analysis (qualitative) and rock core analysis in the laboratory (quantitative). Analysis was carried out on 3 samples of source rock and 6 samples of selected reservoir rock with the following information (Table 1).

Table 1. Sampling location.

\begin{tabular}{cccccccc}
\hline Code & No & X & Y & Locality & Lihology & Sample Code & Analysis \\
\hline FAL & 1 & 685,794 & $9,083,057$ & Argotirto & $\begin{array}{c}\text { Calcareous } \\
\text { claystone }\end{array}$ & FAL001csCL & $\begin{array}{c}\text { Source } \\
\text { Rock }\end{array}$ \\
DEF & 62 & 694,025 & $9,084,340$ & Sekarbanyu & Black shale & DEF062SH & $\begin{array}{c}\text { Geochemistry } \\
\text { LIM }\end{array}$ \\
& 5 & 680,555 & $9,083,739$ & Sumbernanas & Shaly coal & LIM005SH & \\
\hline & 6 & 669,996 & $9,084,960$ & Pagak & Sandstone & TOR006SS & \\
& 10 & 670,631 & $9,084,353$ & Pagak & Clastic limestone & TOR010GK & Reservoir \\
& 12 & 671,061 & $9,083,908$ & Pagak & Sandstone & TOR012SS & Porosity \\
TOR & 31 & 671,619 & $9,085,783$ & Pagak & Clastic limestone & TOR031GK & $\begin{array}{c}\text { Tond } \\
\text { anmeability }\end{array}$ \\
& 35 & 668,007 & $9,085,159$ & Pagak & Clastic limestone & TOR035GK & \\
& 45 & 670,643 & $9,083,659$ & Pagak & Sandstone & TOR045SS & \\
\hline
\end{tabular}

\section{Regional Geology}

\subsection{Regional Stratigraphy}

The Southern Mountains of East Java are generally composed of rocks with Neogene to Quaternary age. This area is mostly dominated by volcanic rock and limestone. Rock sequences are arranged based on detailed stratigraphy through selected paths and presented in a stratigraphic column (Figure 2).

The stratigraphic order from oldest to youngest is as follows:

1) Arjosari Formation (Tma)

The Arjosari Formation consists of turbidite deposits or sediments that are influenced by shearing symptoms that alternate with volcanic rocks, of Late Oligocene Early Miocene age. At the bottom of the formation consists of breccia of various materials, sandstone, tuffaceous sandstone, claystone, sandy marl, and calcareous claystone, with pumice and limestone breccias inserted. The upper 


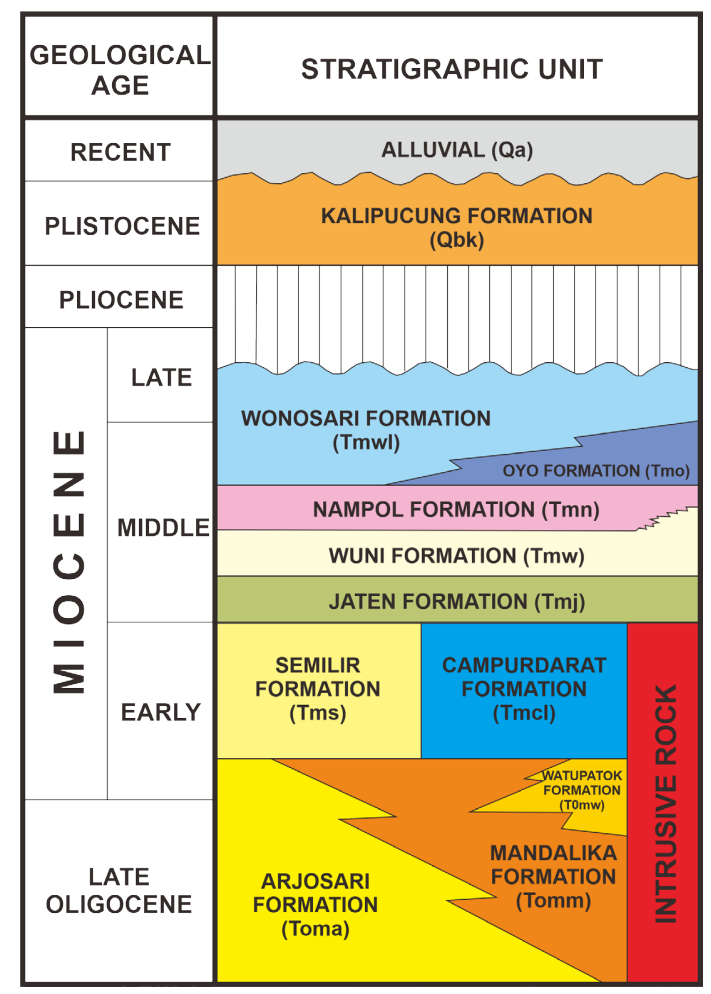

Figure 2. Southern Mountain East Java stratigraphic column [1]. Source rocks are rocks that contain sufficient organic material to create hydrocarbons when subjected to heat and pressure over time [3]. Source rocks are usually shales or limestones (sedimentary rocks). A reservoir rock is a subsurface volume of rock that has sufficient porosity and permeability to permit the migration and accumulation of petroleum under adequate trap conditions [4].

part is interspersed with volcanic breccia, lava, and tuff. Based on its fossil content, the Arjosari Formation is thought to be in the late Oligocene-Late Early Miocene. The Arjosari Formation has a fingering relationship with the Mandalika Formation.

2) Mandalika Formation (Tomm)

The Mandalika Formation is composed of volcanic rock with clastic (volcanic) inserts in a shallow marine environment. The bottom of this formation is composed of repeating volcanic breccias, lava, tuff with inserts of tuffaceous sandstone, claystone, and polymict breccias. In the center of the formation, it is composed of repeating volcanic breccias, lava, and diminishing clastic sediments. At the top of the formation is composed of pillow lava with basalt breccia inserts and tuffaceous claystone. The Mandalika Formation is of Late Oligocene to Early Miocene age with a fingering relationship to the Arjosari Formation.

3) Intrusive Rocks (Tomi)

According to [2], breakthrough rocks intrusive include the above formation with lithology in the form of dacite, andesite, basalt, and diorite. This intrusive rock is in the form of stock, fractured, and localized appearance of a volcanic neck so that it affects the intruded rocks with the age of the Late Oligocene to the end of the Early Miocene, namely the Arjosari and Mandalika Formation. This 
intrusive rock affects the formation of hydrothermally altered rock and low-grade metamorphic in the rock that is breached. This intrusive rock is estimated to be of Late Oligocene to the early Middle Miocene age because of the younger formations (Jaten, Wuni, Nampol, Oyo, and Wonosari Formation) are not affected.

4) Jaten Formation (Tmj)

This formation is composed of terrestrial clastic sediments to shallow (restricted) seas containing debris from land and lignite inserts. The bottom of the unit is composed of conglomerate sandstone, quartz sandstone, tuffaceous sandstone, conglomerate, mudstone; interspersed with claystone and bituminous shale. The upper part is fine clastic sediment in the form of siltstone, claystone, and sandy marl with tuff insertion. Fossil content in the calcareous claystone: Planorbulina sp., Cancris sp., Elphidium sp., Quiqueloculina sp., Dentalina sp., ostracods, pelecypods, and gastropods.

5) Wuni Formation (Tmw)

The Wuni Formation is composed of volcanic rock from Middle Miocene volcanic activity, with the insertion of clastic sediments of volcanic origin, deposited in a shallow marine environment around the Early Miocene highlands. This unit is composed of volcanic breccia and tuff; inserts tuffaceous sandstone, tuffaceous siltstone, claystone, limestone, and lignite. Fossils in this unit are very rare. Based on its stratigraphic position which is younger than the Jaten Formation, this unit is thought to be in the middle of the Middle Miocene. The Wuni Formation has an underlain conformably with the Jaten Formation and overlain conformably by the Nampol Formation.

6) Nampol Formation (Tmn)

This unit is a collection of coarse to fine clastic rocks, interspersed with volcanic rocks and lignite. The bottom of this unit is composed of repeating tuffaceous sandstone, siltstone, and claystone, with volcanic breccia, conglomerate sandstone, and lignite inserted. The upper part is more calcareous, consisting of repeating sandstone, siltstone, claystone; inserts tuff, and lignite. The Nampol Formation is formed in a shallow marine environment adjacent to the loop area with a formation thickness of about $100 \mathrm{~m}$. This formation has a Middle Miocene age and overlain conformably above the Wuni Formation.

7) Oyo Formation (Tmo)

The Oyo Formation is a collection of clastic limestones whose formation is influenced by volcanic activity. Consists of tuffaceous sandstone, calcareous sandstone, calcareous siltstone, sandy limestone, conglomerate limestone; inserting sandy tuff, marl, and conglomerate limestone; inserts sandy tuff, marl, and reef limestone. The lower part of the unit is generally tuffaceous, the higher the tuff element decreases and turns into limestone. Based on the fossil content of small planktonic foraminifera, the Oyo formation has a Middle Miocene age. This formation is formed in a marine environment with a depth of $20-100 \mathrm{~m}$. The Oyo Formation has overlain conformably above the Nampol Formation and has 
a fingering relationship with the Wonosari Formation because the top of the Oyo Formation tends to change facies from tuffaceous clastic to limestone.

8) Wonosari Formation (Tmwl)

This unit is a limestone deposit that is late Middle Miocene and formed in a shallow marine environment. The lower part of the unit is more clastic; consists of sandy limestone (calcarenite) with calcareous sandstones. The upper part is composed of reef limestone, interspersed with calcarenite, marl, and conglomerate limestone. This formation is very rich in small planktonic foraminifera which based on the assemblage they contain have an age of N13 - N16 or Middle Miocene to early Late Miocene.

\subsection{Regional Geological Structure}

In Java, there are three dominant structural patterns [5]. First, the structural pattern with a northeast-southwest direction (Meratus direction) was formed in the Late Cretaceous-Early Eocene age. Second, the structural pattern in the north-south direction (Sunda direction) was formed in the Early Eocene-Early Oligocene age. Third, the structural pattern with a west-east direction (Javanese direction) was formed at the Late Oligocene age by compression forces from the subduction in the southern part of Java Island (Figure 3 ).

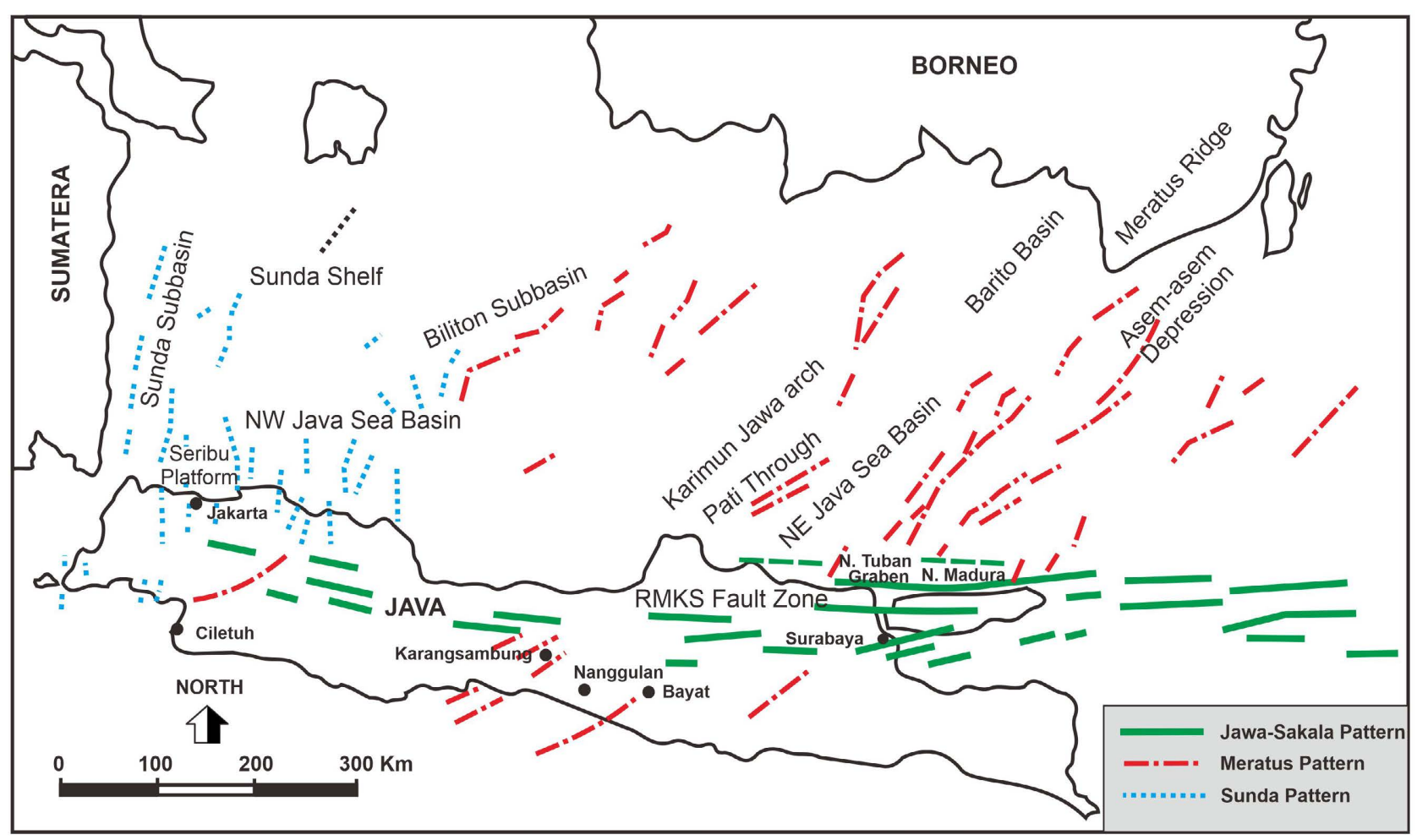

Figure 3. The main structural pattern of Java Island [5].

Reference [6] explained that the eastern part of Java is the intersection of two main structural patterns, the Meratus structure with a northeast-southwest trend and the Sakala structure with an east-west direction. The Meratus direction is 
more developed in the offshore area of the East Java Basin, while the Sakala direction is developing to the eastern part of the mainland of Java (Figure 4).

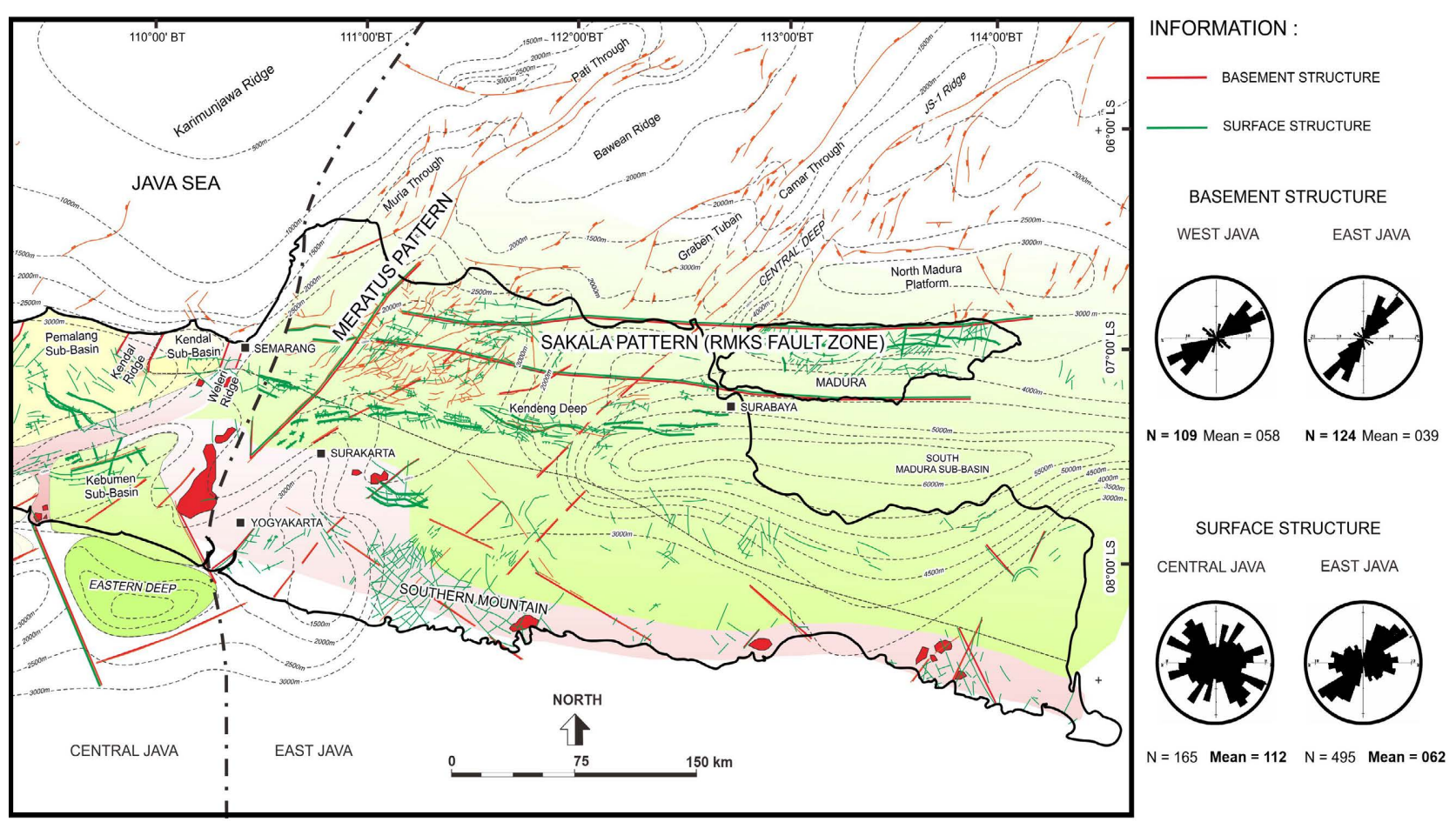

Figure 4. The dominant structures in East Java are the Meratus direction (east-southwest) and the Sakala structure (east-west) [6].

\section{Results and Discussion}

\subsection{Potential Source Rock}

The results of TOC analysis (Table 2) on the source rock samples in the study area showed TOC values of 3.48 - $26.18 \mathrm{wt} \%$ were categorized as good to very good in generating hydrocarbons referring to [7] and [8]. The cross-plot of TOC values was carried out on the values of $S_{1}+S_{2}$ to determine the total generating potential of hydrocarbons that could be produced by each sample. The plotting results show that the total hydrocarbon potential that can be produced for the sample "LP01" is not good; "LP62" is fair, and "LP05" is good (Figure 5).

Table 2. Results of TOC and Rock-Eval Pyrolysis analysis on rock samples in the Nampol Fm.

\begin{tabular}{|c|c|c|c|c|c|c|c|c|c|c|c|c|}
\hline & \multirow{2}{*}{$\begin{array}{l}\text { Sample } \\
\text { ID }\end{array}$} & \multirow{2}{*}{ Lithology } & \multirow{2}{*}{$\begin{array}{l}\text { TOC } \\
(w t \%)\end{array}$} & \multicolumn{3}{|c|}{$\mathrm{mg} / \mathrm{gm}$ rock } & \multirow{2}{*}{$\begin{array}{c}\operatorname{Tmax} \\
\left({ }^{\circ} \mathrm{C}\right)\end{array}$} & \multirow{2}{*}{$\begin{array}{c}\text { Oil } \\
\text { Production } \\
\text { Index (OPI) }\end{array}$} & \multirow{2}{*}{$\begin{array}{c}\text { Potential } \\
\text { Yield } \\
\left(S_{1}+S_{2}\right)\end{array}$} & \multirow{2}{*}{$\begin{array}{l}\text { Hydrogen } \\
\text { Index }\end{array}$} & \multirow{2}{*}{$\begin{array}{l}\text { Oxygen } \\
\text { Index }\end{array}$} & \multirow{2}{*}{$\begin{array}{l}\% \\
\text { Ro }\end{array}$} \\
\hline & & & & $\mathrm{S}_{1}$ & $\mathrm{~S}_{2}$ & $\mathrm{~S}_{3}$ & & & & & & \\
\hline 1 & LP 1 & Calc. claystone & 3.48 & 0.04 & 1.48 & 0.38 & 430 & 0.03 & 1.52 & 43 & 11 & 0.44 \\
\hline 2 & LP 62 & Shale & 4.01 & 0.22 & 3.44 & 2.19 & 417 & 0.06 & 3.66 & 86 & 55 & 0.46 \\
\hline 3 & LP 05 & Shaly Coal & 26.18 & 0.27 & 19.28 & 11.82 & 408 & 0.01 & 19.55 & 74 & 45 & 0.45 \\
\hline
\end{tabular}

$\mathrm{S}_{1}=$ Free Hydrocarbons; $\mathrm{S}_{2}=$ Pyrolysable Hydrocarbons; $\mathrm{S}_{3}=$ Organic $\mathrm{CO}_{2}$. Oil Production Index $=$ Transformation Ratio $=\mathrm{S}_{1} /\left(\mathrm{S}_{1}+\mathrm{S}_{2}\right) ;$ Tmax $=$ Temperature of Maximum $\mathrm{S}_{2}$; Oxygen Index $=\left(\mathrm{S}_{3} / \mathrm{TOC}\right) \times 100 .{ }^{\star}$ Pyrolysis by Rock Eval II; TOC content by Leco Analyzer, Hydrogen Index $=\left(\mathrm{S}_{2} / \mathrm{TOC}\right) \times 100 ;{ }^{\star *}=$ Not Detected. 


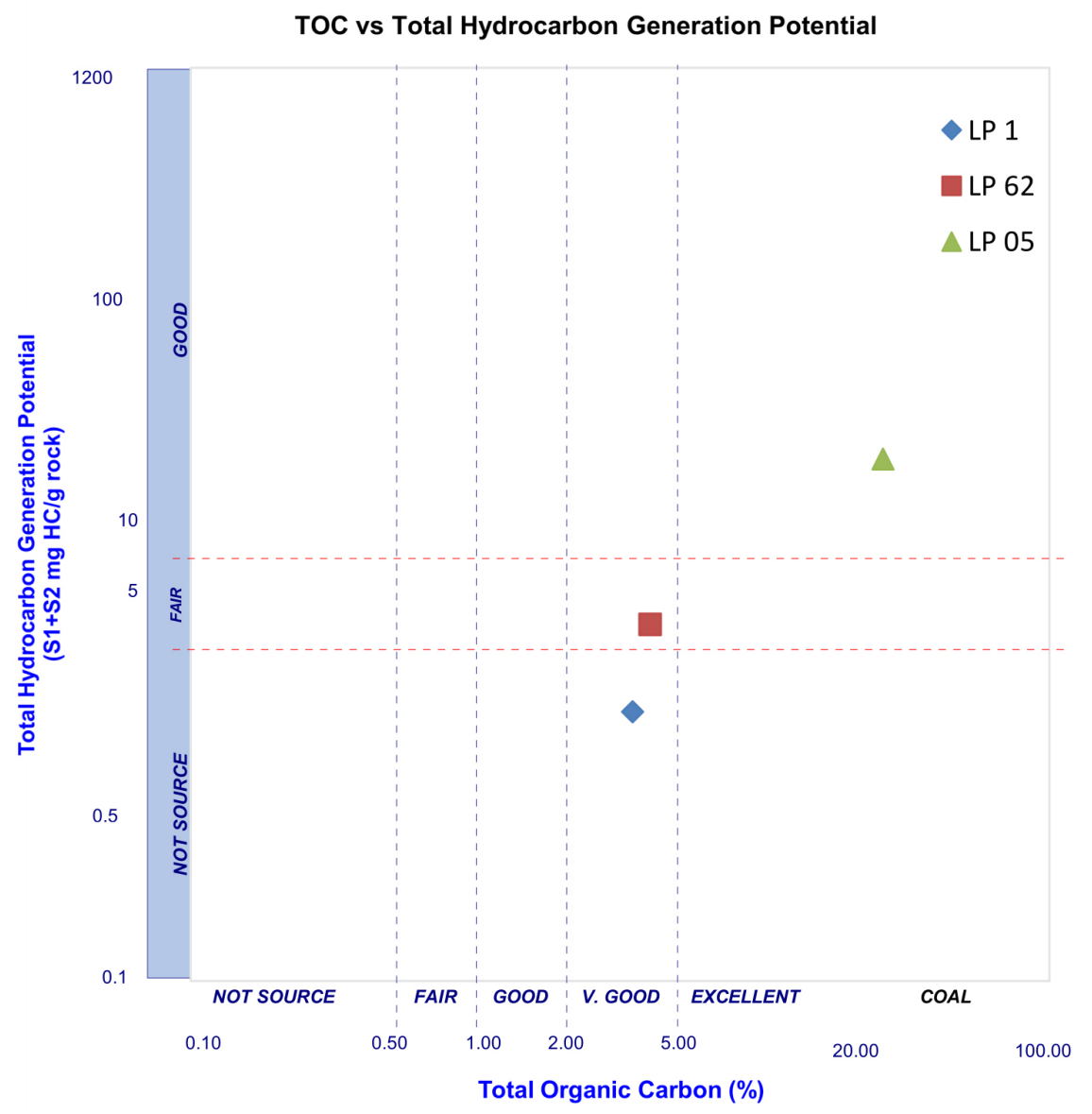

Figure 5. Cross-plot between Total Organic Carbon (TOC) and Potential Yield (PY) content. The results show that the total hydrocarbon potential that can be produced for the code sample "LP01" is not good; "LP62" is fair; and "LP05" is good.

The diagram of the content of Total Organic Carbon (TOC) versus Potential Yield (PY) (Figure 6) shows the potential for hydrocarbons in the study area which is indicated by the level of richness of organic material content. This diagram shows that two samples from the Nampol Formation showed good organic material quality with TOC values of $3.48 \mathrm{wt} \%$ and $4.01 \mathrm{wt} \%$ and PY of 1.52 and $3.66 \mathrm{mgHC} / \mathrm{g}$, respectively. Another sample showed very good organic material quality with a TOC value of $26.18 \%$ and a PY value of $19.55 \mathrm{mgHC} / \mathrm{g}$. The three samples tend to form gas (gas prone) with one of the samples, code LP 05, possess the possibility to become a potential or effective source rock.

Based on the hydrogen index (HI) and of $\mathrm{S}_{2} / \mathrm{S}_{3}$ values, it can be inferred that the type of organic material in the three samples is Type III kerogen (Figure 7). This kerogen contains humic organic matter derived from woody plants containing cellulose from land plants (equivalent to vitrinite in coal) [9].

Vitrinite reflectance (VR) and Rock-Eval Pyrolysis analysis were carried out on rock samples to determine the thermal maturity. From the results of the analysis of vitrinite reflectance in rock samples, values of $<0.5 \%$ Ro are obtained (Table 2). According to the classification of source rock maturity based on vitrinite reflectance value [10], the rock samples are categorized as thermally 
Hydrogen Index vs Oxygen Index (Modified van Krevelen Diagram)

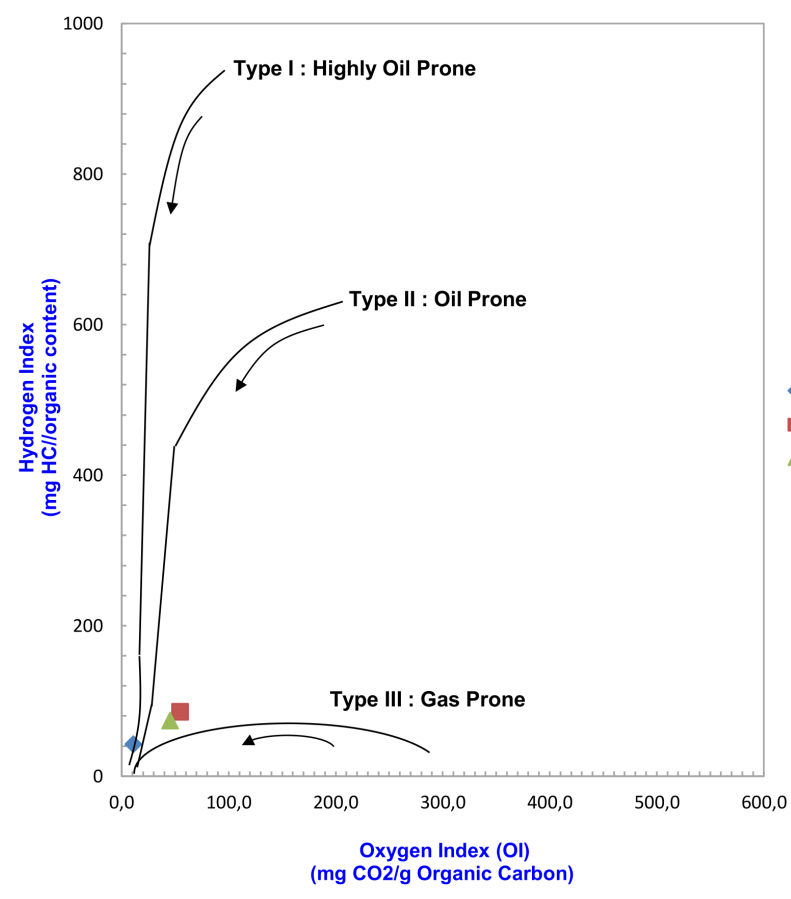

Total Hydrocarbon Generation Potential vs Organic Carbon

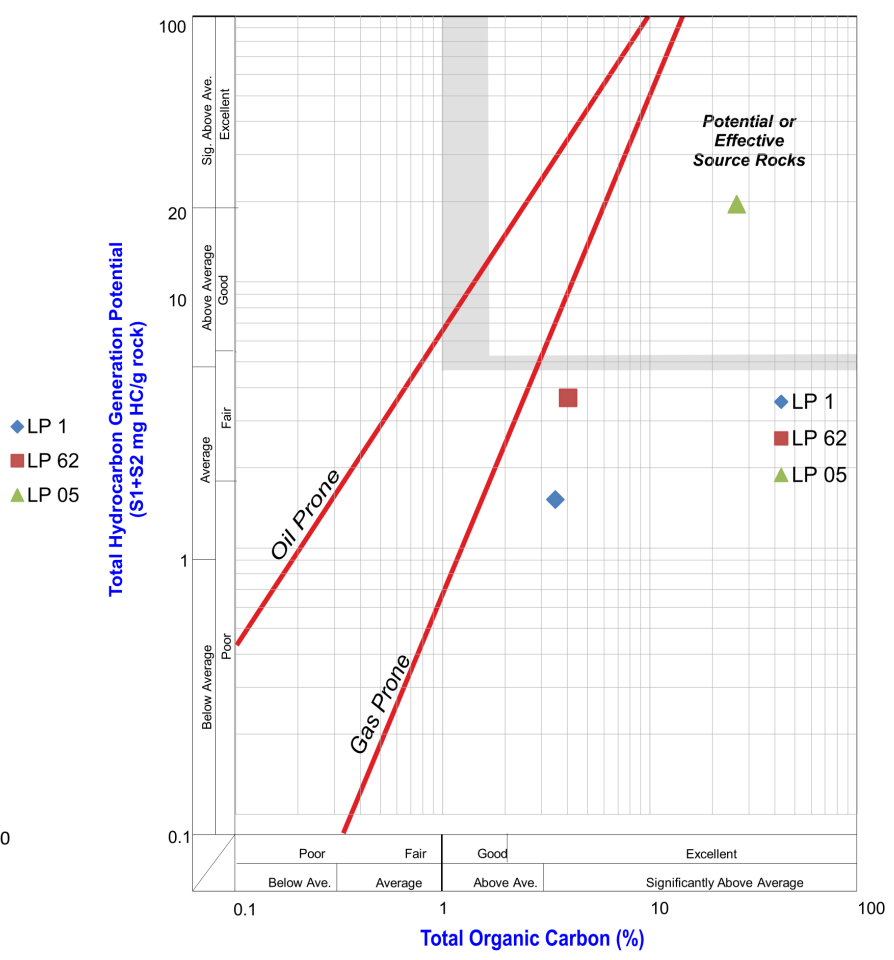

(Bissada \& Kelley, 1989)

Figure 6. Diagram of Total Organic Carbon (TOC) versus Potential Yield (PY) content (left). Cross plot between Oxygen Index (OI) and Hydrogen Index (HI) values (right). All three samples are gas prone.
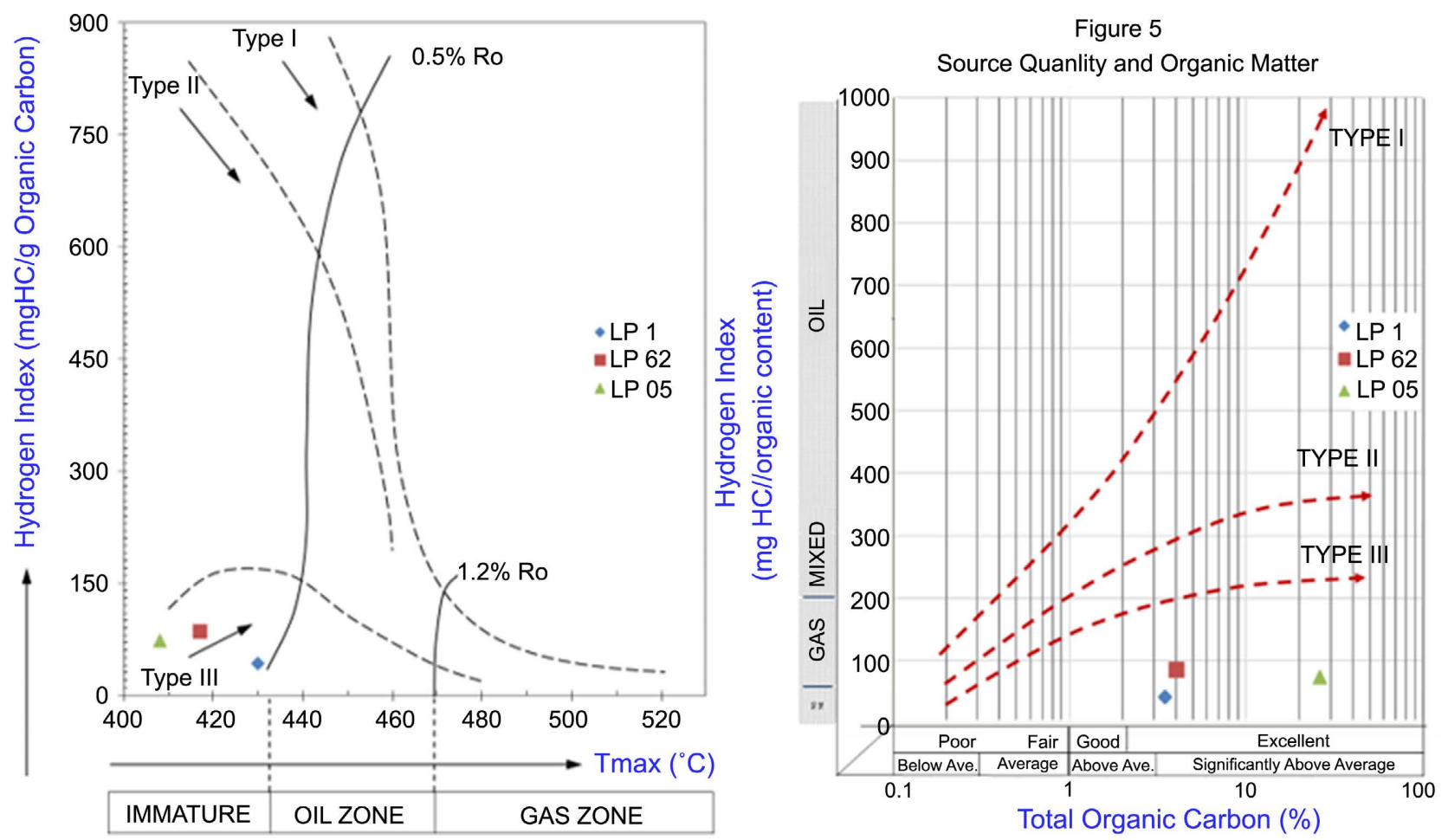

Figure 7. Cross plot between Tmax and Hydrogen Index (HI) values (left). Cross plot between TOC and Hydrogen Index (HI) values (right). The organic material from the three samples were all classified as type III kerogen. 
"Immature" to become hydrocarbon source rocks (Table 3). Meanwhile, the results from Rock-Eval pyrolysis showed that the maximum temperature when breaking the three samples' kerogen are ranged from $408^{\circ} \mathrm{C}$ to $430^{\circ} \mathrm{C}$. According to the Tmax classification and its relationship with the maturity level of the source rock [11], the rock samples are categorized as "Immature" source rock. (Table 3).

Table 3. Guidelines for quantity, quality, and maturity of source rock determination.

\begin{tabular}{|c|c|c|c|c|}
\hline \multirow{2}{*}{\multicolumn{2}{|c|}{ Quantity }} & \multirow{2}{*}{ TOC } & $\mathrm{S}_{1}$ & \multirow{2}{*}{$\frac{\mathrm{S}_{2}}{\mathrm{mgHC} / \mathrm{g} \text { rock }}$} \\
\hline & & & $\mathrm{mgHC} / \mathrm{g}$ rock & \\
\hline \multicolumn{2}{|c|}{ Poor } & $<0.5$ & $<0.5$ & $<2.5$ \\
\hline \multicolumn{2}{|c|}{ Fair } & $0.5-1$ & $0.5-1$ & $2.5-5.0$ \\
\hline \multicolumn{2}{|c|}{ Good } & $1-2$ & $1-2$ & $5-10$ \\
\hline \multicolumn{2}{|c|}{ Very Good } & $2-4$ & $2-4$ & $10-20$ \\
\hline \multicolumn{2}{|c|}{ Excellent } & $>4$ & $>4$ & $>20$ \\
\hline \multirow{2}{*}{\multicolumn{2}{|c|}{ Quality }} & HI & $\mathrm{S}_{2} / \mathrm{S}_{3}$ & \multirow{2}{*}{ Kerogen Type } \\
\hline & & $\mathrm{mgHC} / \mathrm{g}$ TOC & $\mathrm{mgHC} / \mathrm{g}$ rock & \\
\hline \multicolumn{2}{|c|}{-} & $<50$ & $<1$ & IV \\
\hline \multicolumn{2}{|c|}{ Gas } & $20-200$ & $1-5$ & III \\
\hline \multicolumn{2}{|c|}{ Oil and Gas } & $200-300$ & $5-10$ & II/III \\
\hline \multicolumn{2}{|c|}{ Oil } & $300-600$ & $10-15$ & II \\
\hline \multicolumn{2}{|c|}{ Oil } & $>600$ & $>15$ & I \\
\hline \multicolumn{2}{|c|}{ Thermal Maturity } & VR (\%) & $\operatorname{Tmax}\left({ }^{\circ} \mathrm{C}\right)$ & TAI \\
\hline \multicolumn{2}{|c|}{ Immature } & $0.2-0.6$ & $<435$ & $1.5-2.6$ \\
\hline \multirow{3}{*}{ Mature } & Early & $0.6-0.65$ & $435-445$ & $2.6-2.7$ \\
\hline & Peak & $0.65-0.9$ & $445-450$ & $2.7-2.9$ \\
\hline & Late & $0.9-1.35$ & $450-470$ & $2.9-3.3$ \\
\hline \multicolumn{2}{|c|}{ Over mature } & $>1.35$ & $>470$ & $>3.3$ \\
\hline
\end{tabular}

\subsection{Reservoir Quality}

\subsubsection{Qualitative Analysis (Petrographic)}

In the qualitative analysis of porosity, we used ImageJ software. This software has a feature to display microscopic images which then will be analyzed to obtain porosity percentage. The stages of this analysis start from giving blue dye fluid to a petrographic thin section. This liquid will fill in the pores so the pores in the rock thin section will be colored blue. Then, the plate of a thin section is displayed on a microscope. Then the image of the thin section will be taken and displayed on the ImageJ software. The analysis steps using the software are 1) open image, 2) change the image type to 8-bit, 3) adjust threshold, 4) analysis measuring. The porosity percentage results will be obtained afterward (Table 4). After getting the porosity value, the classification is carried out using the porosity classification [12] (Table 5). 
Table 4. Qualitative analysis of reservoir rock porosity. The left column is the petrographic thin section image (PPL), the middle column is an image type 8-bit, and the right image is the result of threshold adjustment.

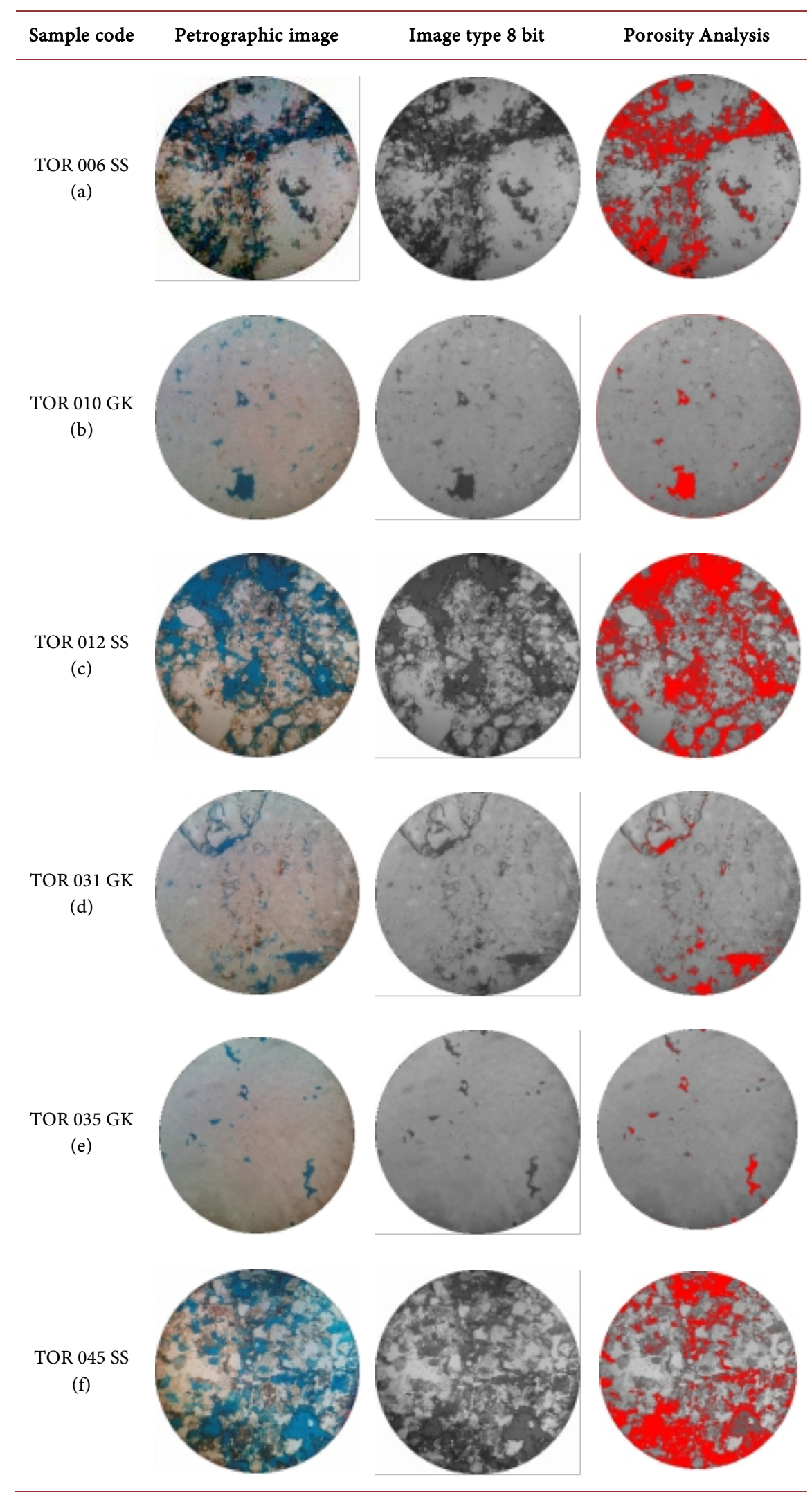


Table 5. Porosity classification [12].

\begin{tabular}{cc}
\hline Value & Classification \\
\hline $0 \%-5 \%$ & Negligible \\
$5 \%-10 \%$ & Poor \\
$10 \%-15 \%$ & Fair \\
$15 \%-20 \%$ & Good \\
$20 \%-25 \%$ & Very Good \\
$>25 \%$ & Excellent \\
\hline
\end{tabular}

The analyzed rocks are part of the Nampol Formation with lithic arenite, mudstone, and floatstone limestones. The lithic arenite (sample code TOR 006 SS) has a porosity value of $9.683 \%$ which is classified as a poor porosity value. The mudstone limestone (sample code TOR $010 \mathrm{GK}$ ) has a porosity value of $1.986 \%$ which is classified as negligible or very poor porosity value. The lithic arenite (sample code TOR 012 SS) has a porosity value of 29.642 which is classified as excellent porosity. The floatstone limestone (sample code of TOR 031 GK) has a porosity value of 4.083 , the porosity value is classified as negligible or very poor. The mudstone limestone (sample code TOR $035 \mathrm{GK}$ ) has a porosity value of 1.377 with the porosity results classified as negligible or very poor. The lithic arenite with sample code TOR 045 SS has a porosity value of 30,464 classified as excellent porosity. All porosities in the 6 samples were primary porosity with intergranular type [13] (Table 6).

Table 6. Qualitative porosity analysis results.

\begin{tabular}{cccccc}
\hline Sample code & Lithology & Formation & Porosity (\%) & Porosity Type & $\begin{array}{c}\text { Porosity } \\
\text { Classification }\end{array}$ \\
\hline TOR 006 SS & Lithic Arenite & Nampol & 9683 & Intergranular & Poor \\
TOR 010 GK & Mudstone & Nampol & 1986 & Intergranular & Negligible \\
TOR 012 SS & Lithic Arenite & Nampol & 29,642 & Intergranular & Excellent \\
TOR 031 GK & Floatstone & Nampol & 4083 & Intergranular & Negligible \\
TOR 035 GK & Mudstone & Nampol & 1377 & Intergranular & Negligible \\
TOR 045 SS & Lithic Arenite & Nampol & 30,464 & Intergranular & Excellent \\
\hline
\end{tabular}

\subsubsection{Rock Core Analysis (Quantitative)}

Laboratory tests were used to provide a quantitative study of porosity and permeability. Six rock samples from the Nampol Formation were subjected to laboratory tests at the Core Analysis Laboratory of Petroleum Engineering Department of UPN "Veteran" Yogyakarta. Three samples of sandstone with sample codes TOR 006 SS, TOR 012 SS, and TOR 045 SS and three samples of clastic limestone with sample codes TOR 010 GK, TOR 031 GK, and TOR 035 GK.

Based on the quantitative analysis results (Table 7), the porosity of lithic arenite is $9.592 \%-22.076 \%$ which indicates poor-very good porosity value. Meanwhile, the clastic limestones have a $1.589 \%-2.643 \%$ porosity value and are clas- 
sified as negligible or very poor porosity value. On the other hand, the permeability test results for sandstone ranging from $83,068 \mathrm{mD}-344,640 \mathrm{mD}$ which is classified as good-very good permeability value. Meanwhile, for clastic limestone, the permeability value of $10,113 \mathrm{mD}-19,873 \mathrm{mD}$ is classified as good permeability values based on the Koesoemadinata classification [12].

Table 7. Quantitative porosity analysis results.

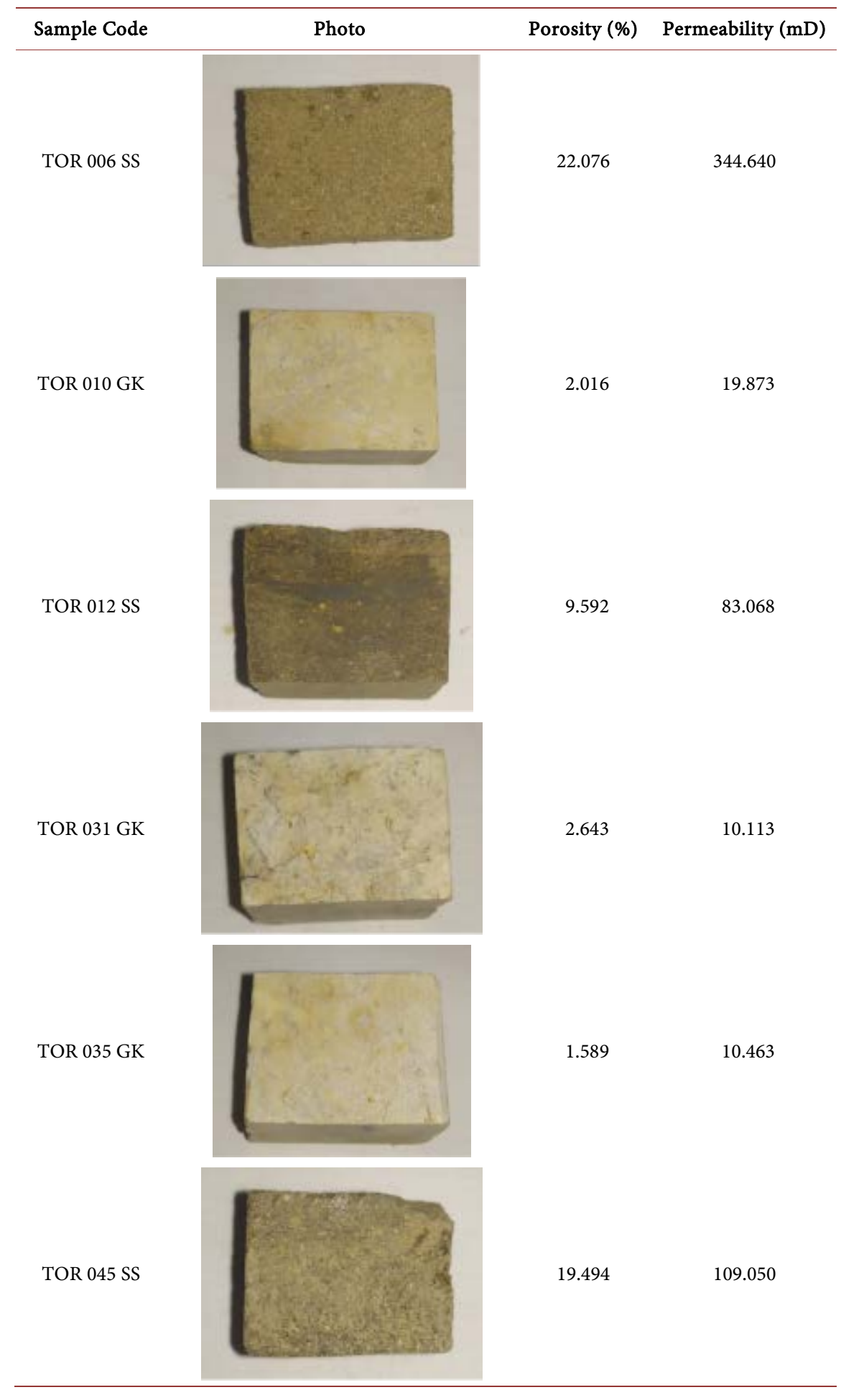




\section{Conclusion}

Based on the results obtained, it can be concluded that black shale and coal in the Nampol Formation are immature source rocks but have the potential to produce hydrocarbons where at the peak of their maturity, it can be predicted its tendency to produce gas. Meanwhile, from the quantitative and qualitative analysis of the porosity and permeability of rocks in the Nampol Formation, it can be concluded that the sandstones of the Nampol Formation have more potential as a reservoir than the clastic limestone units. This study shows that there is a potential for petroleum system existence in the Southern Mountain subvolcanic arc, which is indicated by the presence of potential source rock and reservoir rock as one of the various elements and processes present in a petroleum system.

\section{Acknowledgements}

The research team would like to thank LPPM UPN "Veteran" Yogyakarta, which has provided financial support for this research. We also thank Falkhan, Muslim, Defa, and Guntor, senior geology student of the Department of Geological Engineering UPN "Veteran" Yogyakarta, who have helped in the field and laboratory activities.

\section{Conflicts of Interest}

The authors declare no conflicts of interest regarding the publication of this paper.

\section{References}

[1] Samodra, H. and Wiryosujono, S. (1989) Tinjauan tatanan stratigrafi dan tektonik Pegunungan Selatan Jawa Timur antara Pacitan-Ponorogo. P3G, Bandung, Bandung.

[2] Samodra, H. and Wiryosujono, S. (1993) Stratigraphy and Tectonic History of the Eastern Southern Mountains, Jawa, Indonesia. Jurnal Geologi dan Sumberdaya Mineral, 3, 14-22.

[3] Hyne, N.J. (2012) Nontechnical Guide to Petroleum Geology, Exploration, Drilling \& Production. 3rd Edition, PennWell Books, LLC.

[4] Magoon, L.B. (2004) Petroleum System: Nature's Distribution System for Oil and Gas. In: Cleveland, C.J., Ed., Encyclopedia of Energy, Elsevier Science, Amsterdam, 823-836. https://doi.org/10.1016/B0-12-176480-X/00251-5

[5] Pulunggono, A. and Martodjojo, S. (1994) Perubahan tektonik Paleogen-Neogen merupakan peristiwa tektonik terpenting di Jawa. Proceeding Geologi dan Geotek Pulau Jawa, Yogyakarta, 37-49.

[6] Sribudiyani, N.M. et al. (2003) The Collision of the East Java Microplate and Its Implication for Hydrocarbon Occurrences in the East Java Basin. Proceeding IPA 29th Annual Conference, 1, 335-346.

[7] Peters, K.E. (1986) Guidelines for Evaluating Petroleum Source Rock Using Programmed Pyrolysis. AAPG Bulletin, 70, 318-329. https://doi.org/10.1306/94885688-1704-11D7-8645000102C1865D

[8] Waples, D.W. (1985) Geochemistry in Petroleum Exploration. IHRDC Press, Bos- 
ton, MA. https://doi.org/10.1007/978-94-009-5436-6

[9] Waples, D.W. and Curiale, J.A. (1999) Oil-Oil and Oil-Source Rock Correlations. In: Beaumont, E.A. and Foster, N.H., Eds., Treatise of Petroleum Geologyl Handbook of Petroleum Geology. Exploring for Oil and Gas Traps, AAPG Special Volumes, Tulsa, Oklahoma, USA. https://doi.org/10.1306/TrHbk624C8

[10] Peters, K.E. and Cassa, M.R. (1994) Applied Source Rock Geochemistry. In: Magoon, L.B. and Dow, W.G., Eds., The Petroleum System: From Source to Trap, Vol. 60, American Association of Petroleum Geologists, 93-120. https://doi.org/10.1306/M60585C5

[11] Tissot, B.P. and Welte, D.H. (1978) Petroleum Formation and Occurrence-A New Approach to Oil and Gas Exploration. 1st Edition, Vol. 2, Springer-Verlag Berlin Heidelberg, New York.

[12] Koesoemadinata, R.P. (1980) Geologi minyak dan gasbumi. Penerbit ITB, Bandung.

[13] Choquette, P.W. and Pray, L.C. (1970) Geologic Nomenclature and Classification of Porosity in Sedimentary Carbonates. AAPG Bulletin, 54, 207-250. https://doi.org/10.1306/5D25C98B-16C1-11D7-8645000102C1865D 